\title{
Lithium-chloride-induced aversions in the opossum (Didelphis virginiana)
}

\author{
CARL D. CHENEY and NANCY L. ELDRED \\ Institute of Animal Behavior and Department of Psychology, Utah State University, Logan, Utah 84322
}

\begin{abstract}
No previous studies have reported taste aversions in marsupials. Three experiments are reported wherein opossums, following lithium-chloride-induced illness, avoid drinking saccharinflavored water, avoid killing mice, and stop consuming mice. When the flavors were novel, clear and long-lasting aversions to saccharin and mouse killing were demonstrated in one trial. Attacks ceased, as did consumption. Familiarity with the CS, however, extended the number of illnesses required to establish an aversion. This marsupial shows conditioning similar to some placental mammals, and the findings reported here extend the literature concerning predatory aversion.
\end{abstract}

Many species have been shown to be capable of learning an aversion to a novel flavor. Gustavson (1977) lists 32 different animals, from human to anemone, that have shown conditioned food aversions. The apparent ubiquity of this phenomenon suggests that it is a basic biological process; however, differences exist among species in terms of live prey aversion responses. Some animals will continue to kill but not eat (Etscorn, 1978), whereas others refuse to kill (Gustavson, 1977) after an induced illness. There are other strain (Ader, 1973) and species (Wilcoxon, Dragoin, \& Kral, 1971) differences that are sufficiently interesting to justify investigating the phenomenon more widely.

The genus Didelphis, of which the Virginia opossum (Didelphis virginiana) is one of three species, is one of the most widely distributed mammalian genera in the western hemisphere (Hunsaker, 1977). The didelphids represent a virtually untouched group with great potential for studies in convergent evolution and comparative behavior (Hunsaker \& Shupe, 1977). The Virginia opossum is omnivorous but prefers meat and insects (Hunsaker \& Shupe, 1977). They do show food preferences, but behaviorally and electrophysiologically (Tamar, 1961) they are reported to exhibit little taste sensitivity. Opossums appear to have gustatory responses more similar to those of carnivores than of rodents and are the only animals reported to prefer the bitter taste of quinine over water (Pressman \& Doolittle, 1966). Many characteristics suggest this primitive marsupial to be an informative subject for taste-aversion study.

Aspects of these data were presented at the Rocky Mountain Psychological Association meeting, 1978, and at the Animal Behavior Society meeting, 1978. The authors thank Robert Tarte and Carl Gustavson for comments on an earlier draft. Reprints may be obtained from Carl Cheney, Psychology DepartmentUMC 28, Utah State University, Logan, Utah 84322.
The studies reported here were designed to find out if opossums were capable of acquiring a taste aversion (Kirkby, 1977), to further investigate the dissociation of a killing response from prey eating (Berg \& Baenninger, 1974; Etscorn, 1978; Garcia, Rusiniak, \& Brett, 1977; O’Boyle, Looney, \& Cohen, 1973), and to observe the influence of extended CS exposure on establishing an aversion (Domjan, 1972).

\section{EXPERIMENT 1}

\section{Method}

Subjects. Three opossums (two females, mean weight $3.3 \mathrm{~kg}$; one male, $5.5 \mathrm{~kg}$ ), approximately 10 months of age, served as subjects. They were collected as juveniles following death of the dam and reared briefly at the Portland, Oregon, Zoo. They were housed together in a $1.2 \times 2.5 \mathrm{~m}$ pen, enclosed by $60-\mathrm{cm}$-high walls, with $6 \mathrm{~cm}$ of wood shavings on the floor. Overhead lighting was provided for approximately $10 \mathrm{~h}$ per day, and temperatures varied $\left( \pm 6^{\circ}\right)$ around $19^{\circ} \mathrm{C}$. Maintenance food (dry dog chow) was provided in a single bowl ad lib.

Procedure. For 10 days, the subjects were allowed simultaneous access to $500 \mathrm{ml}$ of tap water for $10 \mathrm{~min}$ each day. On Day 11 (Day 1 of the experiment and following $24 \mathrm{~h}$ of water deprivation), each subject was individually habituated to the empty test arena (a $1 \times 1 \times .5 \mathrm{~m}$ chamber) for $15 \mathrm{~min}$, then presented with a bowl containing $500 \mathrm{ml}$ of tap water flavored by the addition of $250 \mathrm{mg}$ of sodium saccharin. Ten minutes later, the bowl was removed and the amount of water remaining was determined. The animal was replaced in the living space and the next subject was run. Fifteen minutes after removal from the arena, the females were restrained and given ip injections of $25 \mathrm{cc}$ of $.3 \mathrm{M} \mathrm{LiCl}$ and returned to the living space. The male was injected with $25 \mathrm{cc}$ of normal saline as a control. Both experimenters observed the subjects for $1 \mathrm{~h}$ and recorded any indications of illness. These indications included, for the treated females, retching, vomiting, extended attempts to defecate, excessive salivation, and exaggerated tongue and mouth movements. The male showed no signs of distress.

Eight posttreatment tests were conducted over 4 months, with a minimum of 3 days between tests. The baseline 10 -min restrictedwater-access procedure remained in effect throughout. For these tests, two bowls of water were prepared for each subject. One bowl contained $250 \mathrm{ml}$ of tap water, and the other, $250 \mathrm{ml}$ of 
saccharin-flavored tap water as per treatment. Water temperatures were within $1^{\circ} \mathrm{C}$ between bowls. The subject was placed in the arena, and the saccharin bowl was offered first. One minute later, this bowl was exchanged for the plain water bowl. This procedure of alternating bowls each minute continued for $10 \mathrm{~min}$. Amount consumed was determined for each bowl for each minute of the total 5 min that it was offered to the subject. During Tests 5, 6, and 7 , one treated subject was offered the water bowl first.

\section{Results and Discussion}

All subjects adjusted to the restricted watering schedule and did not lose weight. Drinking of saccharinflavored water on the treatment day occurred promptly, and the total fluid consumed was within the range of the total consumed on subsequent test days. No outward signs of rejection (neophobia) appeared at first exposure to the flavor.

Subject 1 drank a mean of $134 \mathrm{ml}$ (range $=90$ $191 \mathrm{ml}$ ) and Subject 2 drank a mean of $146 \mathrm{ml}$ (range $=100-220 \mathrm{ml}$ ) fluid per test. In contrast, the control animal consumed a mean of $230 \mathrm{ml}$ (range $=145$ $298 \mathrm{ml}$ ). Flavored water consumption over the eight tests averaged $53 \%$ of total intake for the control subject (mean $=121 \mathrm{ml}$; range $=85-164 \mathrm{ml})$ and $22.1 \%$ for treated subjects (Subject 1 mean $=47 \mathrm{ml}$, range $=$ $10-90 \mathrm{ml}$; Subject 2 mean $=19 \mathrm{ml}$, range $=2-65 \mathrm{ml}$ ). The treated animals showed a clear and long-lasting aversion.

\section{EXPERIMENT 2}

\section{Method}

Subjects. One male and one female opossum, approximately 1 year old and collected as in Experiment 1, served as treatment subjects (numbers 1 and 2). Two other opossums (one female, one male) served as nontreated controls (numbers 3 and 4). They were housed communally in a $2.5 \times 3 \mathrm{~m}$ pen with wood shavings on the floor and other features as described above.

Apparatus. The predation-test arena was a $.6 \times 1.2 \mathrm{~m}$ pen with sheetmetal sides $(.6 \mathrm{~m} \mathrm{high})$ and a bare metal floor. Treatment injections were administered as in Experiment 1.

Procedure. The subjects were deprived of food (dry dog food) for $48 \mathrm{~h}$ prior to their first exposure to a live mouse (Mus musculus). White mice prey were adult and laboratory reared. The opossum was placed in the arena with a mouse and observed for $30 \mathrm{~min}$ or until a kill. When a kill did occur, the subject was allowed to consume the mouse completely. It was then removed to its home living space for $15 \mathrm{~min}$. Injections were then given ip $(.4 \mathrm{M} \mathrm{LiCl}$, $25 \mathrm{cc}$ total dose), and the subject returned to its pen and observed for $1 \mathrm{~h}$. No food was available. Signs of illness were noted, as in Experiment 1.

Testing consisted of again depriving the subjects for $48 \mathrm{~h}$ and placing them in the arena with a live mouse for $25 \mathrm{~min}$. At least 10 nose-to-nose confrontations between mouse and opossum were considered necessary for an adequate test. In order to ensure adequate opportunities to capture and kill, after $5 \mathrm{~min}$ two or three more live mice were released in the arena. Four such tests were conducted with each subject at 10 -day intervals. Subject 2 received six additional tests, three of which were conducted using dead mice. These prey were killed by cranial trauma immediately prior to being placed in the center of the arena. The purpose of these additional tests was to determine if killing had been dissociated from eating. The dead mouse offered on Session 5 had viscera exposed in an attempt to increase its acceptability.

\section{Results and Discussion}

All subjects in this experiment killed live mice and consumed them upon first exposure. Lithium chloride injections of the two experimental subjects $15 \mathrm{~min}$ following consumption induced many overt signs of illness. Noninjected controls were run for seven killconsume sequences to become CS familiar and were then used as treatment subjects in Experiment 3, described below.

In seven live-prey tests, Subject 2 attempted neither to capture nor to kill a mouse. Many opportunities were provided, as the mice prey were active enough to sometimes crawl up on the opossums. When dead prey were provided (Sessions 4, 5, and 10), Subject 2 neither mouthed nor ate. Subject 1 averted totally for two posttreatment tests, killed and consumed (and was injected) in Session 4, and refused to kill in Session 5 . Subject 1 became ill at this point (arthritis) and was discarded.

It appears clear that, in the case of opossums treated after killing and consuming a single live prey, the predation sequence is not separable. That is, Subject 2 would neither kill nor eat mice. In fact, neither subject would kill after the taste-illness pairing. Berg and Baenninger (1974), on the other hand, found that laboratory-reared rats would continue to kill, but not eat, after such a procedure. Etscorn (1978) found the same in a wild ringtailed cat.

\section{EXPERIMENT 3}

\section{Method}

Subjects and Apparatus. Two adult opossums, numbered 3 and 4 and from the same source as above, were used as subjects. One female $(3.3 \mathrm{~kg})$ and one male $(5.5 \mathrm{~kg})$ were communally housed in a $1.2 \times 2.5 \mathrm{~m}$ living space with a floor covering of wood shavings. They had served as controls in Experiment 2 above.

Testing was conducted in the arena, and injections were given as described in Experiment 2.

Procedure. Each 24-h food-deprived subject was placed in the arena with a live adult white mouse for $30 \mathrm{~min}$. Killing latency was recorded, and the opossum was allowed to consume the item prior to being returned to its home pen. The sessions were 8-10 days apart. Fifteen minutes after being returned to the home pen following the eighth kill-consume trial (Trials 1-7 were part of Experiment 2), both subjects received a $25-\mathrm{cc}$ ip injection of .4 M LiCl. They were observed for signs of illness over the next $1 \mathrm{~h}$. Retching and vomiting usually began about $20 \mathrm{~min}$ after injection. This procedure was repeated on Sessions 9, 10, and 11. On Session 12, no killing occurred within $30 \mathrm{~min}$ and no injection was given. Killing and consumption occurred again on Session 13, and injections were given as above. On the subsequent session (14), no killing occurred and no injection was given.

\section{Results and Discussion}

Opossums in this experiment became very adept at capturing and killing live mice. As a result of treatment, latency to kill was extended from less than $1 \mathrm{~min}$ in Sessions 5-8 to more than $15 \mathrm{~min}$ in Session 11. In Session 13, both subjects killed in the last 5 min of the period. 
In this experiment, four successive taste-illness pairings were required to eliminate a kill-consume sequence, yet, in Session 13, the opossums again sampled the prey. As in Experiment 2, killing was not separable from eating. When killing occurred, consumption followed. After Session 10, both subjects showed signs of discomfort when placed in the test arena, as though the place itself had acquired aversive properties.

\section{GENERAL DISCUSSION}

The subjects in these experiments reacted in much the same way as have placental mammals in many other studies. One exposure to a novel flavor followed by gastrointestinal distress was sufficient to develop an aversion lasting over many test sessions. The saccharin subjects drastically reduced fluid intake after the $\mathrm{LiCl}$ illness. The subjects in Experiments 2 and 3 showed that repeated CS access did not, by itself, lead to avoidance; on the contrary, in Experiment 2 the controls became very efficient.

On the other hand, subjects in Experiment 3, after having killed and consumed mice on eight separate occasions without illness, were very difficult to avert. It was apparent that familiarity with a food item increased resistance to the formation of a hedonic shift away from that item.

The major points include the following. First, marsupials behave similarly to some placental mammals when this taste aversion procedure is used. Second, the finding of a long-lasting aversion to a novel CS and a transitory and difficult-to-establish aversion to a familiar CS supports other results (e.g., Garcia et al., 1977; Rozin, 1977) concerning hedonic shifts. Finally, it appears that, while rats (Berg \& Baenninger, 1974) or ringtailed cats (Etscorn, 1978) may not resist killing mice to which they have been averted, opossums and coyotes (Garcia et al., 1977; Gustavson, 1977) will avoid attacking after one aversion trial. Parameters of the CS controlling such aversions in the present study varied from those of saccharin-flavored water to a live mouse. The evolu- tionary significance of such species differences remains uninvestigated.

\section{REFERENCES}

AdER, R. "Strain" differences in illness-induced taste aversion. Bulletin of the Psychonomic Society, 1973, 1, 253-254.

Berg, D., \& BaEnninger, R. Separation of aggressive and hunger motivation by conditioned aversion. Journal of Comparative and Physiological Psychology, 1974, 86, 601-606.

DomJan, M. CS pre-exposure in taste-aversion learning: Effects of deprivation and pre-exposure duration. Learning and Motivation, 1972, 3, 389-402.

ETsconN, E. Suppression of feeding but not killing of a prey species in the ringtail cat (Bassaricus astutus). Physiological Psychology, 1978, 6, 261-262.

Garcia, J., Rusiniak, K., \& Brett, L. Conditioning foodillness aversions in wild animals: Caveant canonici. In H. Davis \& H. Hurwitz (Eds.), Operant-Pavlovian interactions. Hillsdale, N.J: Erlbaum, 1977.

Gustavson, C. Comparative and field aspects of learned food aversions. In L. Barker, M. Best, \& M. Domjan (Eds.), Learned mechanisms in food selection. Waco, Tex: Baylor University Press, 1977.

Hunsake R, D. Ecology of New World marsupials. In D. Hunsaker II (Ed.), The biology of marsupials. New York: Academic Press, 1977.

Hunsaker, D. J., \& Shupe, D. Behavior of New World marsupials. In D. Hunsaker II (Ed.), The biology of Marsupials. New York: Academic Press, 1977.

KIRKBY, R. Learning and problem-solving behavior in marsupials. In B. Stonehouse \& D. Gilmore (Eds.), The biology of Marsupials. Baltimore: University Park Press, 1977.

O'Boyle, M., Looney, T. A., \& Cohen, P. S. Suppression and recovery of mouse killing in rats following immediate lithium chloride injections. Bulletin of the Psychonomic Society, 1973, 11, 250-252.

Pressman, T. G., \& Doolittle, J. H. Taste preferences in the Virginia opossum. Psychological Reports, 1966, 18, 875-878.

Rozin, P. The significances of learning mechanisms in food selection: Some biology, psychology and sociology of science. In L. Barker, M. Best, \& M. Domjan (Eds.), Learned mechanisms in food selection. Waco, Tex: Baylor University Press.

Tamar, H. Taste reception in the opossum and the bat. Physiological Zoology, 1961, 34, 86-91.

Wilcoxon, H., Dragoin, W., \& Kral, P. Illness induced aversions in rat and quail: Relative salience of visual and gustatory cues. Science, 1971, 171, 826-828.

(Received for publication September 14, 1979; revision accepted March 10,1980.) 